\section{Comparative account on icthyofauna of Pocharam and Wyra lakes of Andhra Pradesh, India}

\section{C.A. Nageswara Rao ${ }^{1}$, J. Deepa ${ }^{2} \&$ Md. Hakeel $^{3}$}

1,2,3 Zoological Survey of India, Freshwater Biology Regional Centre, Plot 366 / 1, Attapur (V), Ring Road, Hyderguda P.O Hyderabad, Andhra Pradesh 500048, India Email: ${ }^{1}$ fbrczsi@gmail.com, ${ }^{2}$ deepajzsi@gmail.com (corresponding author)

Andhra Pradesh has a long tradition of constructing big dams and reservoirs. Some of the oldest man-made lakes in the country are situated in the state: Hussain sagar (500yr old), Saroornagar (275yr), Mir Alam (170yr), Pocharam (90yr), Wyra (77yr) and so on. In the present study two historic lakes of Andhra Pradesh have been selected for taxonomic comparison of fishes. Projects "Limnological and Faunistic Studies on Pocharam Lake, Medak Dist. A.P." (2003-05) and "Limnological and Faunistic Studies on Wyra Lake, Khammam Dist. A.P." (2005-07), were conducted by the Fresh Water Biological Station, Zoological Survey of India/Hyderabad. As a part of the work the faunal diversity of fish fauna of these lakes have been studied.

Fishes are very important from the biodiversity point of view enjoying different ecosystems, habitats, and niches of aquatic environment. A limited number of

Date of publication (online): 26 February 2011

Date of publication (print): 26 February 2011

ISSN 0974-7907 (online) | 0974-7893 (print)

Editor: K. Rema Dev

Manuscript details:

Ms \# 01933

Received 28 January 2008

Final received 04 January 2011

Finally accepted 17 January 2011

Citation: Rao, C.A.N., J. Deepa \& M. Hakeel (2011). Comparative account on icthyofauna of Pocharam and Wyra lakes of Andhra Pradesh, India. Journal of Threatened Taxa 3(2): 1564-1566.

Copyright: () C.A. Nageswara Rao, J. Deepa \& Md. Hakeel 2011. Creative Commons Attribution 3.0 Unported License. JoTT allows unrestricted use of this article in any medium for non-profit purposes, reproduction and distribution by providing adequate credit to the authors and the source of publication.

Acknowledgements: The authors are grateful to the Director, Zoological Survey of India (ZSI), Kolkata for providing facilities and encouragement to carry out this work.

OPEN ACCESS | FREE DOWNLOAD studies have also been carried out on ichthyofauna of some specific wetlands of Andhra Pradesh (Chacko 1949; David 1963; Dutt

\& Reddy 1979; Barman 1993 \& Chandrasekhar 2003). The fish fauna of Medak District has been studied by Rahimullah (1944). The fish fauna of Khammam District was partially studied by Barman (1993).

Pocharam Lake: The largest and the most important reservoir of the Medak District is the Pocharam Reservoir (water spread area $16.835 \mathrm{~km}^{2}$, with a depth of about $6-7 \mathrm{~m}$ ) formed by damming the Aleru River. It was constructed between 1916 and $1922\left(18^{\circ} 08^{\prime} \mathrm{N} \& 7^{0} 57^{\prime} \mathrm{E}\right)$ about $100 \mathrm{~km}$ north-west of Hyderabad in Medak and Nizamabad districts. Owing to its unique location and the presence of forested tracts, the vertebrate faunal diversity is rich in comparison to other lakes.

Wyra Lake: Wyra Lake is located to the north of Wyra Town, about $25 \mathrm{~km}$ south of Khammam between Khammam and Kothagudem towns in Khammam District. It was constructed in 1930. The lake is located $2 \mathrm{~km}$ off the Hyderabad-Visakhapatnam highway, and is surrounded by greenery. Its water is unpolluted and potable and serves nearly 20,000 acres for cultivation and provides drinking water for 70 villages. The water spread area of the lake is about $19.166 \mathrm{~km}^{2}$.

\section{Material and Methods}

During the course of quarterly surveys in connection with the faunistic studies of the Pocharam and Wyra lakes, fish collections were made with the help of hand operated nets of varying sizes by randomly netting different areas of the wetland. Fishermen were engaged to operate cast-nets to collect the fishes. Some fish were collected from fishermen when they were fishing, and also at the time of harvesting. Fish from various sublocalities of Pocharam Lake (Pocharam Village, Pochammaralu, Rajpet, burugupalle, Polkampet, Wadalaparthy and Kottapalle, were collected during three quarterly surveys from July 2003 to April 2005.) From Wyra Lake (Siddiq Nagar, Singarayepalem, Lallurigudem, Mallavaram, Narayanapuram, Reddigydem and Brahmanapalle) fish were collected during three quarterly surveys from April, 2006-March, 2008). The specimens were fixed in $10 \%$ formalin. Fishes were identified with the aid of 
standard literatures on the groups viz. Jayaram (1999), Talwar \& Jhingran (1991), and Menon (1999).

Systematic account: From Pocharam Lake 24 species under 12 families and six orders were recorded from a total of 755 specimens collected and from Wyra Lake 22 species of fishes under 17 genera, 11 families and six orders from a total of 808 specimens were collected (Table 1).

\section{Discussion}

The icthyofauna of both lakes are dominated by cyprinid and cobitid species (Cypriniformes) followed by the species of perches (Perciformes) and species of other orders. Geographically both lakes are in the Deccan Plateau and are natural tributaries of the Godavari River which are meant for agriculture, fish harvesting and drinking water supply to nearby villages. These two lakes are not influenced by urban sewage and are surrounded by semi-deciduous forest with sugar cane, cotton and paddy fields. Physicochemical parameters of both lakes show similarities like temperatue $\left(26-32{ }^{\circ} \mathrm{C}\right), \mathrm{pH}(7.5-7.8)$, DO (2.5$3.9 \mathrm{mg} / \mathrm{l})$, etc. Because of the many similarities, the ichthyofaunal diversity is found to be similar with a few exceptions. The seedlings of commercially important fishes like Catla and Labeo are introduced by the fisheries society. Most of the fishes are common to both lakes with some exceptions like Etroplus suratensis, Channa striatus and Rhinomugil corsula which are are found only in Wyra Lake. Etroplus suratensis, a shoaling fish, is very common in the estuaries and thrives well where luxuriant growth of aquatic vegetation is available. Dense vegetation, many water plants, hiding places and open swimming areas are suitable for this species in Wyra Lake. Another fish which is reported only in Wyra Lake, Rhinomugil corsula which thrives well in estuarine waters, is also reported from the Krishna River basin. The mixing of waters of the Krishna-Godavari river basins explains the occurrence of Rhinomugil corsula in Wyra. Whereas, one specimen of Ompok bimaculatus was reported in Pocharam Lake. This is generally not cultured in lakes but might have made its entry through the Godavari River system. Some of the riverine fishes such as Sperata seenghala, Wallago attu and Rhinomugil corsula are found to be inhabiting lentic waters such as lakes and reservoirs, so the maintenance of healthy environment of lentic
Table 1. List of fish species occurring in Pocharam and Wyra lakes.

\begin{tabular}{|c|c|c|}
\hline Species & $\begin{array}{c}\text { Pocharam } \\
\text { Lake }\end{array}$ & $\begin{array}{l}\text { Wyra } \\
\text { Lake }\end{array}$ \\
\hline \multicolumn{3}{|l|}{ Notopteridae } \\
\hline 1. Notopterus notopterus (Pallas) & + & + \\
\hline \multicolumn{3}{|l|}{ Cyprinidae } \\
\hline 2. Salmostoma bacaila (Hamilton) & + & - \\
\hline 3. Chela laubuca (Hamilton) & + & - \\
\hline 4. Parluciosoma.daniconius (Hamilton) & + & + \\
\hline 5. Osteobrama vigorsii (Hamilton) & + & - \\
\hline 6. Puntius sophore (Hamilton) & + & + \\
\hline 7. Puntius ticto (Hamilton) & + & + \\
\hline 8. Catla catla (Hamilton) & + & + \\
\hline 9. Labeo rohita (Hamilton) & + & + \\
\hline \multicolumn{3}{|l|}{ Balitoridae } \\
\hline 10. Schistura d. denisoni (Day) & + & - \\
\hline \multicolumn{3}{|l|}{ Bagridae } \\
\hline 11. Mystus vittatus (Hamilton) & + & + \\
\hline 12. Mystus cavasius (Hamilton) & + & + \\
\hline 13. Sperata seenghala (Sykes) & + & + \\
\hline \multicolumn{3}{|l|}{ Siluridae } \\
\hline 14. Ompok bimaculatus (Bloch) & + & - \\
\hline 15. Wallago attu (Schneider) & + & + \\
\hline \multicolumn{3}{|l|}{ Belonidae } \\
\hline 16. Xenentodon cancila (Hamilton) & + & + \\
\hline \multicolumn{3}{|l|}{ Mastacembelidae } \\
\hline 17. Macrognathus pancalus (Bloch) & + & + \\
\hline 18. Mastacembelus armatus (Hamilton) & + & + \\
\hline \multicolumn{3}{|l|}{ Ambassidae } \\
\hline 19. Chanda nama (Hamilton) & + & + \\
\hline 20. Parambassis ranga (Hamilton) & + & + \\
\hline \multicolumn{3}{|l|}{ Cichlidae } \\
\hline 21. Etroplus maculatus (Bloch) & + & + \\
\hline 22. Etroplus suratensis (Bloch) & - & + \\
\hline \multicolumn{3}{|l|}{ Mugilidae } \\
\hline 23. Rhinomugil corsula & - & + \\
\hline \multicolumn{3}{|l|}{ Gobiidae } \\
\hline 24. Glossogobius giuris (Hamilton) & + & + \\
\hline \multicolumn{3}{|l|}{ Belontidae } \\
\hline 25. Polyacanthus fasciatus (Schneider) & + & - \\
\hline \multicolumn{3}{|l|}{ Channidae } \\
\hline 26. Channa punctatus (Bloch) & + & + \\
\hline 27. Channa striatus (Bloch) & + & + \\
\hline
\end{tabular}


waters helps in the conservation of some riverine fishes. In recent times, fishes, especially freshwater fishes of the Indian region, are being threatened due to loss of habitat, as rivers are being dammed or diverted and wetlands are cleared for agriculture and for other purposes. Deleterious effects also result from over fishing, catching of breeding fish and fry, pollution of rivers and streams. Protection and conservation of lakes helps in maintaining the freshwater ichthyofaunal diversity to some extent.

\section{REFERENCES}

Barman, R.P. (1993). Pisces: Freshwater fishes, India: State fauna series 5, Fauna of Andhra Pradesh, Part-I, ZSI Publication, 89-334pp.

Chacko, P.I. (1949). The Krishna River and its fishes. Proceedings of 36th National Science Congress 3: 165
Chandrasekhar, S.V.A. (2003). Ichthyo Fauna of Kondakarla Lake, Andhra Pradesh. Records of the Zoological Survey of India 101(1-2): 179-187.

David, A. (1963). Studies on Fish and Fisheries of the Godavari and the Krishna river systems. Part I, Proceedings of the National Academic Science, Section B 33(2): 263:286.

Devi K.R. \& T.J. Indra (2003). An Updated Checklist of Icthyofauna of Eastern Ghats. Zoos' Print Journal 18(4): 1067-1070.

Dutt, S. \& P.B. Reddy (1979). On the Snake head fishes of Andhra Pradesh. Memoirs of the Society of Zoology (Guntur) 1: 103-108

Jayaram, K.C. (1999). The Freshwater Fishes of the Indian Region. ZSI, Govt of India, xxvii+509pp.

Menon, A.G.K. (1999). Check List- Freshwater Fishes of India, Records of the Zoological Survey of India Occaional Paper 175: i-xxix+366pp.

Rahimullah, M. (1944). Fish Survey of Hyderabad State Part III - Fishes of the Medak District. Journal of the Bombay Natural History Society XIV: 73-77.

Talwar, P.K. \& A. Jhingran (1991). Inland Fishes. Vol. I, Oxford-IBH, New Delhi, 542pp. 